\title{
ECONOMIC ANALYSIS OF DIFFERENT HYDRAULIC SPRAYERS USED IN SUGARCANE (Saccharum spp.)
}

\author{
Neisvaldo B. dos Santos ${ }^{1 *}$
}

${ }^{1 *}$ Corresponding author. Universidade Federal do Piauí - UFPI/Bom Jesus - PI, Brasil. Doutorando em Engenharia Agrícola (Engenharia de Sistemas Agrícolas) pela Universidade Federal do Ceará - UFC/Fortaleza - CE, Brasil.

E-mail: neisvaldo@gmail.com | ORCID: http://orcid.org/0000-0001-6167-5747

\section{KEYWORDS}

agricultural mechanization, computer model, cost, mill revenue, planning and management, sugarcane mill.

\begin{abstract}
Brazil is the largest sugarcane producer worldwide. In mills, sugarcane crops are sprayed with agrochemicals using self-propelled, tractor-driven, and aerial hydraulic sprayers. As sugarcane spraying is regularly performed over extensive areas, the machinery to be used should be planned and dimensioned to ensure timely operations without overloading and at lower costs. Therefore, the current study aimed to analyze the operational and economic performances of different hydraulic sprayers to perform sugarcane crop control. As long as meeting our goal in field conditions would be difficult, we opted to develop a computational model, named as "TratoCana", using a spreadsheet and programming language. The model was used to assess economic and operational factors by generating scenarios and analyzing probable routine errors. In short, the results evidenced that initial value and operation speed are factors with the strongest impact on the costs of self-propelled sprayers and tractor-sprayer sets. Yet, the aerial application was mostly affected by fuel costs and crop row lengths. Moreover, the larger the spray tank volume, the lower the costs.
\end{abstract}

\section{INTRODUCTION}

During the 2017/2018 growing season, sugarcane grown area in Brazil was estimated at 8.76 million hectares, with a production estimate of 646.34 million tons (CONAB, 2017). These are extensive areas and have to be regularly sprayed for pest and disease control. However, the planning and management of such operations are essential to ensure that they meet the established a steady and timely pace. Moreover, the planning of spraying routines could also avoid unfavorable weather conditions and improve application efficiency, reducing agrochemical losses and maximizing operational costs, among others. According to Dash \& Sirohi (2008), Sichonany et al. (2011), and Akinnuli et al. (2014), agricultural mechanized operations should be planned and managed previously for punctuality, without under- or overloading machinery and having minimal operational costs.

The absence of planning and management in agricultural machinery has resulted in discrepant reductions and increases in operation times. Accordingly, Hansen et al. (2007) studied a row crop harvesting pattern by combines for turning maneuvers, considering four platform sizes $(6,8,12$, and 16-row heads); they observed that the 12-row platform provided the shortest turn time in a row crop.

Agricultural spraying machines can be selected by their operational and economic performances. Basically, operational performance is measured by the following parameters: operating speed, field efficiency, operational field capacity, worked hours, machine hours, and the number of machines required. In turn, economic performance is given by fixed costs per year and per hour, and those with fuel consumption, repair and maintenance services, and operational costs (Mialhe, 1974; Balastreire, 1990; Hunt, 1995).

According to Jokiniemi et al. (2012), Rivera et al. (2012), Shamshiri \& Ismail (2013), Zaied et al. (2014), and Oduma et al. (2015), field efficiency has a direct influence on the operational field capacity of a machine and on mechanized operations themselves. As stated by Araldi et al. (2013), Zhou et al. (2015), and Santos et al. (2018), mechanized operations are performed considering operational times to improve their field efficiency. In this line, Yousif et al. (2013), Ma et al. (2015), and Cervi et al. (2015) claimed that field efficiency is the ratio between the effective time spent in harvesting operations and the total time that a machine remains in the field.

Currently, computer modeling has been adopted to manage agricultural machinery selection. For Santos et al. (2015), such tool facilitates the development of structures and generation of scenarios to be used in a selecting process. Still, according to the same authors, the use of computer models for planning and management of agricultural machines provides acceptable solutions to the arising problems. 
Mercante et al. (2010) developed a software, named "PRAPRAG", based on programming language and concluded that self-propelled sprayers have variable costs similar to those of agricultural tractors. Likewise, Faria \& Silva (2015) built a model to assess the effects of changes in a maintenance program of mechanized sugarcane harvesting and observed reductions in maintenance rates from $10.0 \%$ to $3.5 \%$. Khoub Bakht et al. (2009), Rashidi \& Ranjbar (2010), and Niari et al. (2012) also developed some models to analyze the roles of spare parts, operator and mechanic wages, lubricants, oil filter, and fuel consumption in the costs with tractor repairment and maintenance. Similarly, Rohani et al. (2011) elaborated a model to solve cost issues with tractor repairment and maintenance.

In short, agricultural machinery management consists of systematically selecting optimum machines, once performance parameters are interrelated among themselves. Therefore, the aim of the current study was to analyze the operational and economic performances of different hydraulic sprayers used in sugarcane crops.

\section{MATERIAL AND METHODS}

A sample scenario was developed for a fictitious sugarcane mill, considering an area of 22,000 ha, a mean sugarcane yield of $80.00 \mathrm{Mg} \mathrm{ha}^{-1}$, and a price paid to growers for delivered sugarcane of US\$ $22.04 \mathrm{Mg}^{-1}$, in accordance with UDOP (2016). For this scenario, the spraying of agrochemicals was carried out by three hydraulic sprayers: self-propelled, tractor-driven, and aerial sprayers. Table 1 shows the economic, technical, and operational features of the selected machines.

TABLE 1. Economic, technical, and operational variables of the selected machines.

\begin{tabular}{|c|c|c|c|c|c|c|}
\hline Variable & Abbr. & Unit & Self-propelled Sprayer & Tractor & Sprayer & Aircraft \\
\hline Initial Value & IV & US\$ & 197,500 & 44,063 & 43,750 & 270,313 \\
\hline Nominal Power & Pow & $\mathrm{kW} / \mathrm{CV}$ & $147 / 200$ & $74 / 100$ & - & $238 / 324$ \\
\hline Number of Tips & NT & Number & 56 & - & 49 & 42 \\
\hline Space Between Tips & SBT & $\mathrm{m}$ & 0.50 & - & 0.50 & 0.3571 \\
\hline Total Tank Volume & TTV & $\mathrm{L}$ & 3,000 & - & 3,000 & 950 \\
\hline Operation Speed & OS & $\mathrm{m} \mathrm{s}^{-1}$ & 2.50 & \multicolumn{2}{|c|}{2.50} & 61.67 \\
\hline Turning Speed & $\mathrm{TS}$ & $\mathrm{m} \mathrm{s}^{-1}$ & 1.39 & \multicolumn{2}{|c|}{1.39} & - \\
\hline Replenishment Speed & RS & $\mathrm{m} \mathrm{s}^{-1}$ & 5.56 & \multicolumn{2}{|c|}{5.56} & - \\
\hline Running Speed from Runway to Crop Field & SFTC & $\mathrm{m} \mathrm{s}^{-1}$ & - & \multicolumn{2}{|c|}{-} & 77.78 \\
\hline
\end{tabular}

A computational model, named "TratoCana" (version 2.0), was developed aiming at meeting the main characteristics of mechanized spraying for sugarcane cultivation. This model was developed in an Excel ${ }^{\mathbb{R}}$ spreadsheet and was based on the Visual Basic ${ }^{\circledR}$ programming language. Figure 1 shows the flowchart of the model, which was elaborated according to the symbology proposed by Oakland (2007).

After starting its operation $(1)^{2}$, the next steps consisted of inputting (2) crop data such as the area to be sprayed, mean sugarcane yield, and price paid per ton of sugarcane; (3) climate data such as total number of spraying days, worked days, relative air humidity, air temperature, and wind speed; and (4) operational pace based on crop and climate data.
Then, data entry was performed using information about: (5) technical and operational features of terrestrial spraying application such as tip number, tip spacing, tip flow, replenishment time, pump-to-field mean distance, mean crop row length, operation speed, turning maneuver speed, replenishment speed, total tank volume, field efficiency, among others; and (6) technical and operational features of aerial spraying application such as tip number, tip spacing, and tip flow, replenishment time, runway-tofield mean distance, mean crop row length, operation speed, runway-to-field running speed, effective row width, each return curve time, ground time between flights, aerial application rate, total tank volume, field efficiency, among others.

${ }^{2}$ The numbers in parentheses refer to the steps in the flowchart illustrated in Figure 1. 


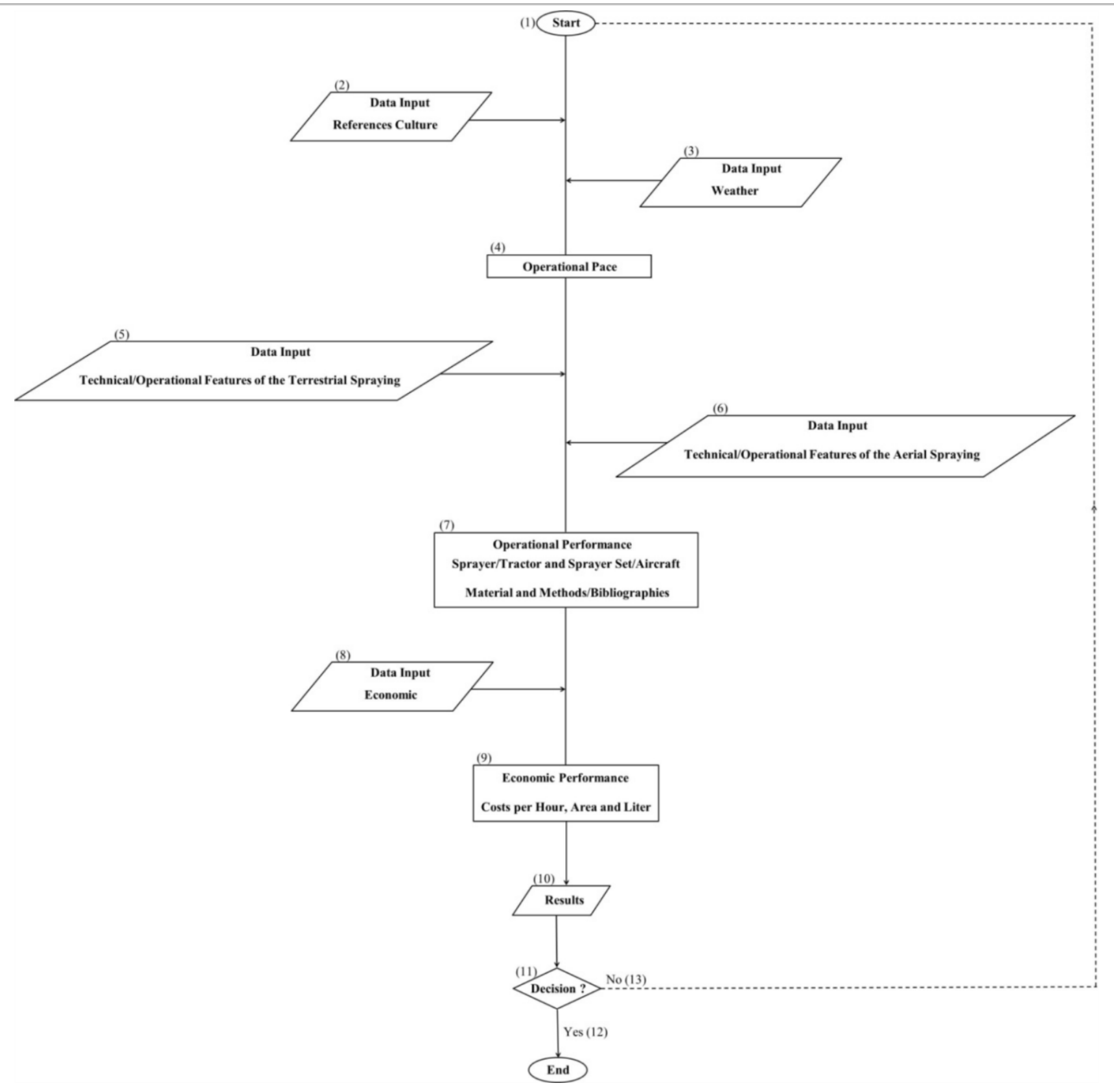

FIGURE 1. Computer model general flowchart.

The operational pace associated with the technical and operational features of all spraying systems was used to determine the operational performance of the evaluated machines, sprayer ${ }^{3}$, tractor-sprayer set, and aircraft, (7) using available time, operational field capacity, application volume, total application flow rate, total time for displacement and replenishment, total traveled distance, machine hours, and number of required machines.

The results of operational performance were associated to machinery economic data (8) such as initial and final values of machines; lifespan (in years and hours); interest per year; lodging, insurance, and taxes (LIT); fuel consumption; repair and maintenance service, among others. These enabled us to calculate their economic performances (9) in terms of costs per hour, area, and liter.

In brief, the results generated by the model (10) allow users to assess both operational and economic performances of mechanized spraying operations, and to infer (11) whether it was feasible (12) or not. As the operation was deemed unfeasible (13), new data should be inserted into the model, or another scenario has to be devised.

\section{Agroclimatic factors}

The factor 'climate' for the fictitious mill was established based on the number of working days inappropriate for spraying (NWDIS), as proposed by Santos (2017). This approach takes into account agroclimatic parameters such as relative air humidity (RH), wind speed (WS), and air temperature (T). Therefore, for this purpose, mean values of agroclimatic parameters from Rio Largo County - AL (Brazil) in 2014 were used (Table 2). These data were obtained from the agrometeorological station located in the Center for Agricultural Sciences of the Federal University of Alagoas (CECA/UFAL).

${ }^{3}$ When the word "sprayer" is mentioned alone in the text, it refers to a self-propeller machine. 
TABLE 2. Mean values of agroclimatic parameters used in the model scenario.

\begin{tabular}{|c|c|c|c|c|c|c|c|c|c|c|c|c|c|c|}
\hline \multirow{2}{*}{ Parameter } & \multirow{2}{*}{ Abbr. } & \multirow{2}{*}{ Unit } & \multicolumn{12}{|c|}{ Month } \\
\hline & & & Jan & Feb & Mar & Apr & May & Jun & Jul & Aug & Sept & Oct & Nov & Dec \\
\hline Air Temperature & $\mathrm{T}$ & ${ }^{\circ} \mathrm{C}$ & 26.15 & 26.05 & 26.75 & 27.70 & 25.70 & 24.50 & 23.95 & 23.35 & 24.65 & 24.65 & 26.25 & 25.60 \\
\hline Relative Air Humidity & RH & $\%$ & 65.65 & 67.60 & 67.40 & 68.91 & 71.75 & 69.20 & 67.35 & 69.95 & 70.60 & 69.05 & 63.95 & 66.10 \\
\hline Wind Speed & WS & $\mathrm{m} \mathrm{s}^{-1}$ & 2.00 & 1.70 & 1.70 & 1.50 & 1.50 & 1.70 & 1.70 & 1.70 & 1.80 & 1.90 & 1.90 & 1.90 \\
\hline
\end{tabular}

Source: CECA/UFAL

As suggested by Mialhe (1974), the number of working days inappropriate for spraying (NWDIS) was also considered as available time (AT) (Equation 1). Thus, available time (AT) was calculated by adding the number of working days inappropriate for spraying (NWDIS) and the number of sundays and holidays (NSH), discounting the number of days (ND) and then multiplying it by the working hours (WH).

$$
\mathrm{AT}=\{[\mathrm{ND}-(\mathrm{NSH}+\mathrm{NWDIS})] * \mathrm{WH}\}
$$

Where,

$$
\begin{aligned}
& \text { AT = available time }(\mathrm{h}) ; \\
& \mathrm{ND}=\text { number of days; } \\
& \mathrm{NSH}=\text { number of Sundays and Holidays; }
\end{aligned}
$$$$
\text { NWDIS }=\text { number of working days inappropriate }
$$$$
\text { for spraying, and }
$$

$\mathrm{WH}=$ working hours $(\mathrm{h})$.

\section{Operational performance}

The operational performances of both the sprayer and the tractor-sprayer set were measured as proposed by Mialhe (1974), aiming at defining the number of required machines for the spraying of agrochemicals in the sugarcane field of the assessed mill.

The number of machines (NM) was estimated by the ratio between the operation pace (OP) and operational field capacity (OFC) of the machine (Equation 2).

$$
\mathrm{NM}=\frac{\mathrm{OP}}{\mathrm{OFC}}
$$

Where,

$$
\begin{aligned}
& \mathrm{NM}=\text { number of machines; } \\
& \mathrm{OP}=\text { operation pace }\left(\text { ha } \mathrm{h}^{-1}\right) \text {, and } \\
& \mathrm{OFC}=\text { operational field capacity }\left(\mathrm{ha} \mathrm{h}^{-1}\right) .
\end{aligned}
$$

The operational pace (OP) was measured by the ratio between the area to be sprayed (AS) and available time (AT) to perform the agricultural operation.

Operational field capacity (OFC) was estimated by the association of total boom width (TBW), operation speed (OS), and field efficiency (FE).

The volume of spraying solution to be applied was determined in accordance with the guidelines of Matuo et al. (2010) (Equation 3). Application volume (AV) was the ratio between tip flow (TF) and the spacing between tips (SBT), multiplied by operation speed (OS).

$$
A V=\left[\frac{(\mathrm{TF} \times 600)}{(\mathrm{SBT} \mathrm{OS})}\right]
$$

Where,

$$
\begin{aligned}
& \mathrm{AV}=\text { application volume }\left(\mathrm{L} \mathrm{ha}^{-1}\right) ; \\
& \mathrm{TF}=\text { tip flow }\left(\mathrm{L} \mathrm{min}^{-1}\right) ; \\
& \mathrm{SBT}=\text { spacing between tips }(\mathrm{m}) ; \text { and } \\
& \mathrm{OS}=\text { operation speed }\left(\mathrm{Km} \mathrm{h}^{-1}\right) .
\end{aligned}
$$

Total application flow (TAF) was defined by the association between application volume (AV) and operational field capacity (OFC).

Displacement time for replenishment (DTR) corresponds to the time for back and forth to the field, calculated as the ratio between the field-to-pump mean distance (FPMD) and replenishment speed (RS).

In turn, the total time for displacement and replenishment (TTDR) corresponded to the total time spent going to the pump, replenishing, and returning to the field. It was measured by summing displacement time for replenishment (DTR) and replenishment time (RT).

The number of replenishments (NR) was established according to the relationship among application volume (AV), area to be sprayed (AS), and total tank volume (TTV).

Turning maneuver distance (TMD) was established as the turning radius of the machinery by doing a turning (TRMT).

The time to finish each turning (TFT) was estimated as the ratio between turning maneuver distance (TMD) and turning speed (TS).

The number of turning maneuvers (NTM) was defined as the relationship among area to be sprayed (AS), total boom width (TBW), and mean length of rows (MLR).

To define the number of required machines for aircraft spraying, the measurement of the operational performance also followed the proposal of Mialhe $\left(197^{4}\right)$, as described for the sprayer and for the tractor-spray set.

The operational field capacity (OFC) of aerial spraying was calculated as adjusted model of Araújo (2009), associating the total volume of sprayer tank (TVST), application volume (AV), distance between runway and the field (DRF), running speed from runway to the field (RSRF), effective row width (ERW), operation speed (OS), time for each return curve (TRC), mean length of rows (MLR), and ground time between flights (GTF).

\section{Sprayer economic performance}

The total cost of the sprayer (TCS) was determined by associating the operational cost of the sprayer (OCS) and the area to the sprayed (AS), as follows (Equation 4).

${ }^{4}$ When the text only addresses the word 'set', it means the tractor and sprayer (dragged or mounted). 


\section{$\mathrm{TCS}=\mathrm{OCS} * \mathrm{AS}$}

Where,

$\mathrm{TCS}=$ total sprayer cost $(\mathrm{US} \$) ;$

OCS $=$ sprayer operational cost $\left(\mathrm{US} \$ \mathrm{ha}^{-1}\right)$; and

$\mathrm{AS}=$ area to be sprayed (ha).

The operational cost of the sprayer (OCS) was defined as the ratio between the cost of sprayer per hour $(\mathrm{CSH})$ and its operational field capacity (OFC) (Equation 5).

$$
\mathrm{OCS}=\frac{\mathrm{CSH}}{\mathrm{OFC}}
$$

Where,

$$
\begin{aligned}
& \mathrm{OCS}=\text { sprayer operational cost }\left(\mathrm{US} \$ \mathrm{ha}^{-1}\right) ; \\
& \mathrm{CSH}=\text { cost of the sprayer per hour }\left(\mathrm{US} \$ \mathrm{~h}^{-1}\right), \text { and } \\
& \mathrm{OFC}=\text { operational field capacity }\left(\mathrm{ha} \mathrm{h}^{-1}\right) .
\end{aligned}
$$

The operational cost of the application of the sprayer (OCAS) was established as the ratio between the cost of the sprayer per hour $(\mathrm{CSH})$ and total application flow (TAF) (Equation 6).

$$
\text { OCAS }=\frac{\text { CSH }}{\text { TAF }}
$$

Where,

OCAS = operational cost of the application of the sprayer (US\$ L ${ }^{-1}$ );

$\mathrm{CSH}=$ cost of the sprayer per hour $\left(\mathrm{US} \$ \mathrm{~h}^{-1}\right)$, and

$\mathrm{TAF}=$ total application flow $\left(\mathrm{L} \mathrm{h}^{-1}\right)$.

The cost of the sprayer per hour $(\mathrm{CSH})$ was calculated by summing the hourly fixed cost of the sprayer (HFCS) with the variable cost of the sprayer (VCS), in which hourly fixed cost of the sprayer (HFCS) was based on the proposal of ASABE (2011) (Equation 7), being the ratio between annual fixed cost (AFC) and number of worked hours per year (NWHY).

$$
\mathrm{HFCS}=\frac{\mathrm{AFC}}{\mathrm{NHWY}}
$$

Where,

HFCS $=$ hourly fixed cost of the sprayer $\left(\mathrm{US} \$ \mathrm{~h}^{-1}\right)$;

$\mathrm{AFC}=$ annual fixed cost $\left(\mathrm{US} \$\right.$ year $\left.^{-1}\right)$, and

NWHY $=$ number of worked hours per year $\left(\right.$ h year $\left.{ }^{-1}\right)$.

Yet, the variable costs of the sprayer (VCS) accounted for the sum of costs with fuel (FC) and with repair and maintenance services (RMC) (Equation 8).

$$
\mathrm{VCS}=\mathrm{FC}+\mathrm{RMC}
$$

Where,

$$
\begin{aligned}
& \mathrm{VCS}=\text { variable sprayer cost }\left(\mathrm{US} \$ \mathrm{~h}^{-1}\right) \\
& \mathrm{FC}=\text { fuel cost }\left(\mathrm{US} \$ \mathrm{~h}^{-1}\right), \text { and } \\
& \mathrm{RMC}=\text { repair and maintenance costs }\left(\mathrm{US} \$ \mathrm{~h}^{-1}\right) .
\end{aligned}
$$

Sprayer fuel consumption was calculated by an adaptation of Banchi et al. (2008), in which the mean consumption by motor power range of agricultural tractors was considered.

Repair and maintenance costs (RMC) was estimated using the repair and maintenance factor (RMF) as in ASABE (2011) (Equation 9).

$$
\mathrm{RMC}=\left(\frac{\mathrm{RMF}^{*} \mathrm{Iv}}{\mathrm{ULh}}\right)
$$

Where,

$$
\begin{aligned}
& \mathrm{RMC}=\text { repair and maintenance costs }\left(\mathrm{US}^{-1}\right) ; \\
& \mathrm{RMF}=\text { repair and maintenance factor }(\text { Decimal); } \\
& \mathrm{Iv}=\text { initial value of the machine (US\$), and } \\
& \mathrm{ULh}=\text { useful life in hours }(\mathrm{h}) .
\end{aligned}
$$

\section{Tractor-sprayer economic performance}

Total (TCTS), operational (OCTS), application operational (OCATS), and hourly (HCTS) costs of the set ${ }^{4}$ were calculated as were those of the sprayer.

Just as done for the sprayer, the hourly fixed costs of the set (HFCTS) were calculated based on the method suggested by ASABE (2011). Also, the variable costs of the set (VCTS) were determined by summing costs with tractor fuel (CTF) and repair and maintenance costs (RMC) (Equation 10).

$$
\text { VCTS }=\mathrm{CTF}+\mathrm{CRM}
$$

Where,

$$
\begin{aligned}
& \text { VCTS = variable cost of the set }\left(\mathrm{US} \$ \mathrm{~h}^{-1}\right) ; \\
& \mathrm{CTF}=\text { cost with tractor fuel }\left(\mathrm{US} \$ \mathrm{~h}^{-1}\right) \text {, and } \\
& \mathrm{RMC}=\text { repair and maintenance costs }\left(\mathrm{US} \$ \mathrm{~h}^{-1}\right) .
\end{aligned}
$$

Fuel consumptions means were considered for calculations, which were based on the nominal power rate of an agricultural tractor, as suggested by Banchi et al. (2008).

Just as for the sprayer, repair and maintenance costs (RMC) and repair and maintenance factor (RMF) of the set were calculated according to ASABE (2011).

\section{Aircraft economic performance}

For the aircraft, either the total and operational costs (TCA and OCA) and application operational and hourly costs (AOCA and HCA) were calculated as those of the sprayer alone and the tractor-sprayer set.

The calculations of hourly fixed cost (HFCA) followed the method proposed by ASABE (2011), just as for the sprayer and the set. Yet, the variable cost of aerial spraying (VCA) was determined as the sum of fuel cost (FC) and repair and maintenance costs (RMC), just like that of the sprayer.

Airplane fuel consumption was considered as the mean value consumption because of its higher power and a more intense working regime, as proposed in EMBRAER/NEIVA (2012). 
As done for the sprayer and the set, repair and maintenance costs (RMC) of the aircraft was determined according to ASABE (2011), while the repair and maintenance factor (RMF) used data provided by PBA AVIATION (2012).

\section{Mill revenues}

Gross and net revenues of the fictitious mill were estimated by an adaptation of the calculations done by Santos et al. (2015). This calculation integrates raw material losses in the gross revenue and mechanized harvesting costs in the net revenue. Thus, the gross revenue of the mill (GRM) encompassed sugarcane ton price (STP) and sugarcane yield (SY), whereas the net revenue of the mill (NRM) considered the difference between gross revenue of the mill (GRM) and total cost (TC) of the machine.

\section{Validation}

The computational model "TratoCana" (version 2.0) was validated by setting the simulation results against raw data (primary) from the field and against the bibliographic findings (secondary). Furthermore, model sensitivity and consistency were assessed by the cost analysis.

\section{RESULTS AND DISCUSSION}

The mean values of climatic parameters used for the mill refer to the data recorded in Rio Largo County AL (Brazil) in 2014. Such parameters resulted in a number of working days inappropriate for spraying (NWDIS) of 257 and available time (AT) of 2,583 hours.

According to the results found for the model scenario shown in Figure 2, annual interest (25.99\%) (AI) was the most representative factor in sprayer cost, followed by annual depreciation (25.67\%) (AD), and lodging, insurance, and taxes (LIT) $(6.42 \%)$, totaling $58.08 \%$ (Figure 2a). As these three items compose the fixed costs, the variable costs represented $41.93 \%$ of the total.
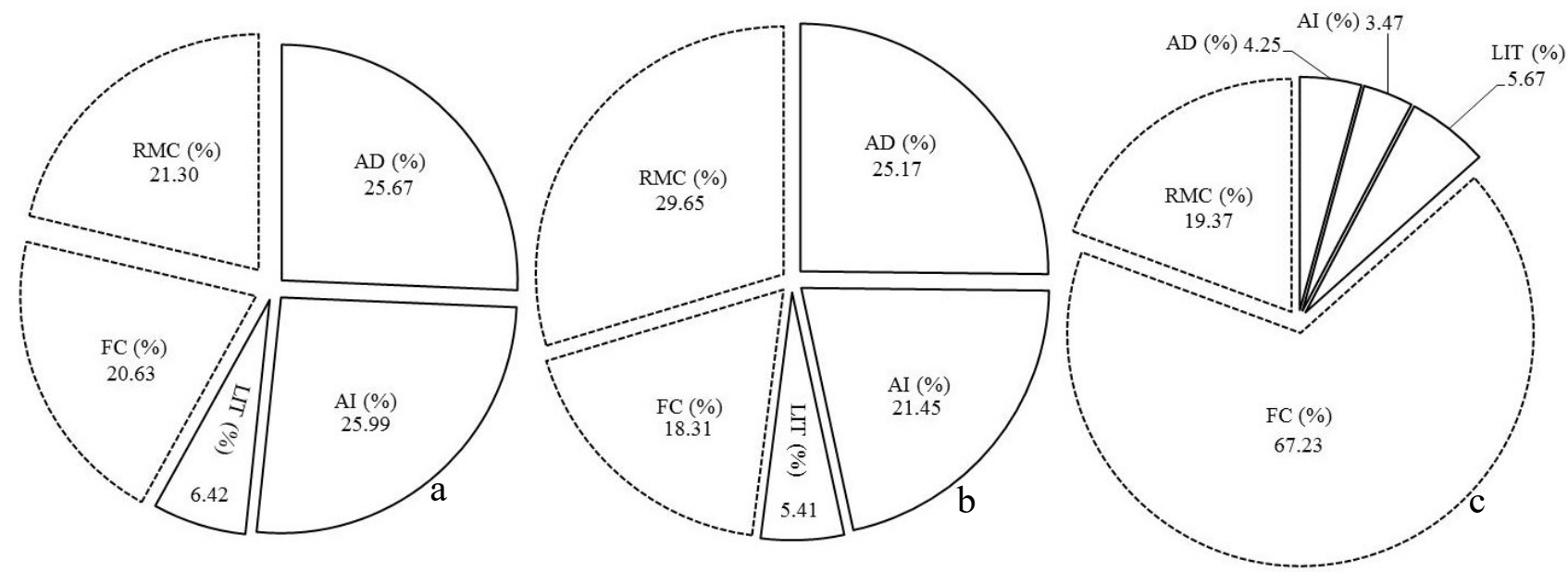

FIGURE 2. Distribution of costs (\%) in the model scenario: a - sprayer, b - tractor-sprayer set, and c - aircraft. AD - Annual depreciation; AI - Annual interest; LIT - Lodging, insurance, and taxes; RMC - Repair and maintenance costs; and FC - Fuel cost.

For the set, the repair and maintenance costs (RMC) had the greatest expression in costs $(29.65 \%)$, followed by annual depreciation (AD) (25.17\%). Fixed costs totaled $52.03 \%$ and variable costs accounted for $47.96 \%$ (Figure 2b). Fuel cost (FC) was the most representative parameter for the aircraft $(67.23 \%)$, followed by repair and maintenance costs (RMC) $(19.37 \%)$, totaling $86.60 \%$ of the variable costs and $13.39 \%$ of the fixed costs (Figure 2c).
Figure 3 shows that the minimum area for the sprayer, the set, and the aircraft were 261, 228, and 92 ha, and had operational costs of $158.97,85.04$, and 325.51 US\$ ha ${ }^{-1}$, respectively. Decreases in cost were due to the amortization of fixed costs with machinery, on the basis of worked hours. The larger the area, the longer the worked hours using machines, until the operational field capacity (OFC) was unable to meet the operation pace (OP). This leads to the entrance of a new machine into the field, i.e., two more sprayers, tractor-sprayer sets, and aircraft. 


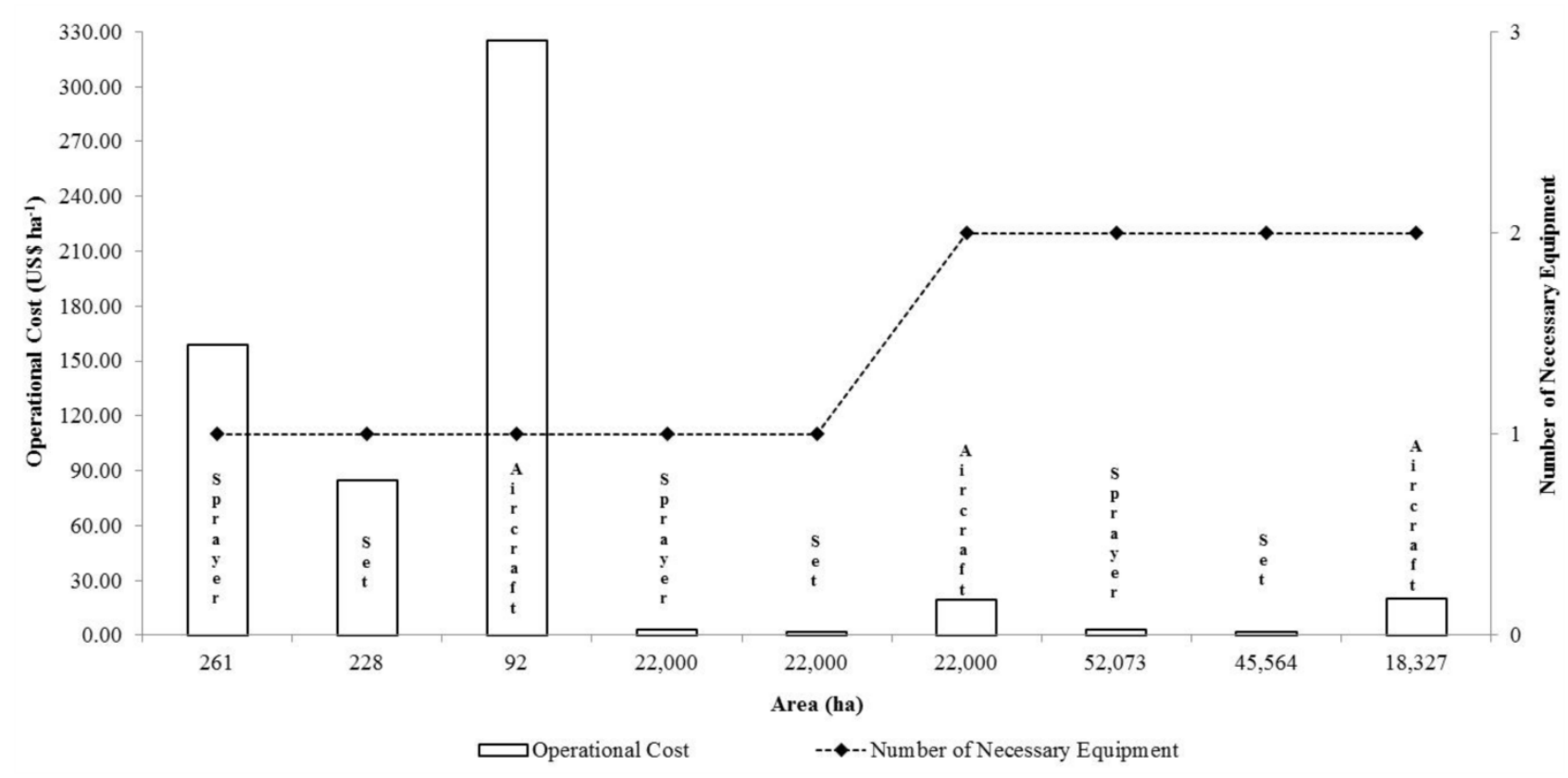

FIGURE 3. Operational cost and number of machines required as a function of the area to be sprayed.

Both the sprayer (261 ha) and the set (228 ha) worked 11 hours, while the aircraft ( 92 ha) operated 12 hours. For the sprayer, the need for a second machine occurred from 52,073 ha sprayed, totaling 2,245 worked hours. For the set, it was from 45,564 ha sprayed, i.e., 2,272 worked hours. And, lastly, there was a need for another aircraft from 18,327 ha (i.e., 2,322 worked hours).
As can be seen in Figure 4, the total cost of machinery use has a share in the revenue of the fictitious mill. According to the used scenario, the sugarcane yield (SY) was $1,760,000 \mathrm{Mg}$ and the gross revenue of the mill (GRM) was US\$ 38,791,500. Accordingly, the total cost (TC) of the sprayer reached a share of $0.18 \%$, resulting in a net revenue of the mill (NRM) of $99.82 \%$ or US\$ $38,720,659.06$ (Figure 4a).

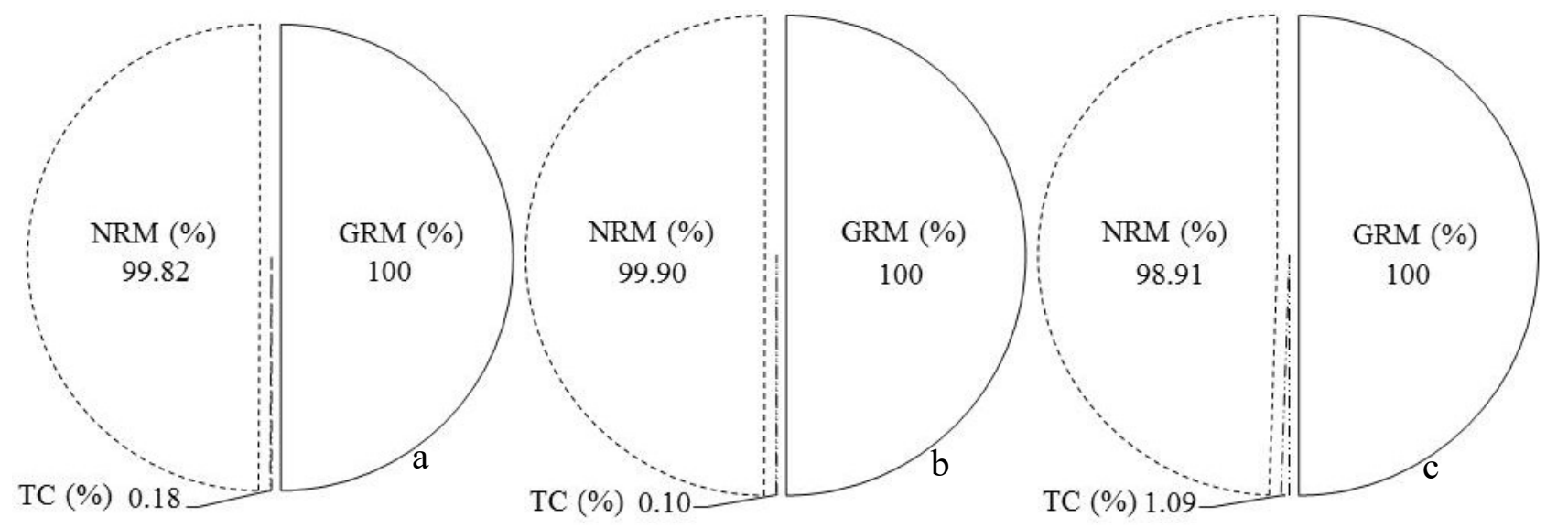

FIGURE 4. Distribution (\%) of the gross revenue (GRM), net revenue of the mill (NRM), and total cost (TC) of the machinery: a - Sprayer, b - Tractor-sprayer Set, and c - Aircraft.

For the set, total cost (TC) was $0.10 \%$ and the net revenue of the mill (NRM) was $99.90 \%$ or US\$ $38,754,590.63$ (Figure 4b). If compared to the sprayer, there was a cost difference of $0.09 \%$ (US\$ 33,931.88) in the net revenue of the mill (NRM). The aircraft was the one that most impacted the gross revenue of the mill (GRM) since it reached $1.09 \%$ (Figure 4c) and, when compared to the sprayer, showed a difference of $0.91 \%$ and of $1.00 \%$ if compared to the set.

\section{CONCLUSIONS}

In the mechanized spraying system, the aircraft had the highest operational costs.
The tractor sprayer set had the least impact on the gross revenue of the mill, followed by the self-propelled sprayer and the aircraft.

\section{REFERENCES}

Akinnuli BO, Akerele FO, Nathaniel ABC (2014) Model developed for farm tractors and implements selection for optimum utilization. Journal of Emerging Trends in Engineering and Applied Sciences 5(4):248-255. Available: http://jeteas.scholarlinkresearch.com/articles/Model\%20Dev eloped $\% 20$ for $\% 20$ Farm $\% 20$ Tractors.pdf. 
ASABE - American Society of Agricultural and Biological Engineers (2011) Agricultural machinery management data ASAE D497.7. In: ASABE Standards, 8p.

Araldi PF, Schlosser JF, Frantz UG, Ribas RL, Santos PM dos (2013) Eficiência operacional na colheita mecanizada em lavouras de arroz irrigado. Ciência Rural 43(3):445451. Available:

http://www.scielo.br/scielo.php?pid=S010384782013000300011\&script=sci_abstract\&tlng=es. DOI: http://dx.doi.org/10.1590/S0103-84782013000300011

Araújo EC (2009) Aviação agrícola: voando alto. Cultivar Máquinas (82):20-24.

Balastreire LA (1990) Máquinas agrícolas. São Paulo, Manole, 307p.

Banchi AD, Lopes JR, Zago CA (2008) Uso anual e consumo de combustível em frotas agrícolas. Revista Agrimotor (39):8-10.

Cervi RG, Esperancini MST, Silva HOF, Isler PR, Oliveira PA (2015) Avaliação do desempenho operacional da colheita e transbordo de cana-de-açúcar (Saccharum spp.). Revista Energia na Agricultura 30(3):232-241. Available:

http://revistas.fca.unesp.br/index.php/energia/article/view/1534. DOI: http://dx.doi.org/10.17224/EnergAgric.2015v30n3p232-241

CONAB - Companhia Nacional de Abastecimento (2017) Acompanhamento da safra brasileira: cana-de-açúcar, segundo levantamento (área plantada e produção). Brasília, DF, CONAB. Available:

http://www.conab.gov.br/OlalaCMS/uploads/arquivos/17 08_24_08_59_54_boletim_cana_portugues_-_2o_lev__17-18.pdf. Accessed: 07 Mar, 2017.

Dash RC, Sirohi NPS (2008) A computer model to select optimum size of farm power and machinery for paddy-wheat crop rotation in Northern India. Agricultural Engineering International: CIGR Journal 10:1-12. Available: http://www.cigrjournal.org/index.php/Ejounral/article/view/1245.

EMBRAER/NEIVA - Empresa Brasileira de Aeronáutica (2012) Especificações: características principais ipanemão $100 \%$ etanol. EMBRAER/NEIVA. Available:

http://www.embraeragricola.com.br/Documents/Spec_FIN AL\%20APROVADO.pdf. Accessed: 07 Mar, 2016.

Faria LFF de, Silva JEAR da (2015) Effects of maintenance management procedures in sugarcane mechanic harvesting system equipment. Engenharia Agrícola 35(6):1187-1197. Available:

http://www.scielo.br/scielo.php?script=sci arttext\&pid=S010 0-69162015000601187. DOI: http://dx.doi.org/10.1590/18094430-Eng.Agric.v35n6p1187-1197/2015

Hansen AC, Zhang Q, Wilcox TA (2007) Modeling and analysis of row harvest harvesting patterns by combines. Transactions of the ASABE 50(1):5-12. Available: https://elibrary.asabe.org/abstract.asp?aid=22397. DOI: $10.13031 / 2013.22397$

Hunt D (1995) Farm power and machinery management. Iowa State University Press, 363p.
Jokiniemi T, Rossner H, Ahokas J (2012) Simple and cost effective method for fuel consumption measurements of agricultural machinery. Agronomy Research 10:97-107. Special Issue 1. Available: http://agronomy.emu.ee/vol10Spec1/p10s110.pdf.

Khoub Bakht GM, Ahmadi H, Akram A, Karimi M (2009) Repair and maintenance cost models for $\mathrm{mf} 285$ tractor: a case study in central region of Iran. Advances in Biological Research 3(1-2):19-23. Available: https://www.idosi.org/abr/3(1-2)/4.pdf.

Ma S, Scharf PA, Karkee M, Zhang Q (2015) Performance evaluation of a chopper harvester in Hawaiian sugarcane fields. Transactions of the ASABE 58(2):271-279. Available: https://elibrary.asabe.org/abstract.asp?aid=44613. DOI: $10.13031 /$ trans.58.10834

Matuo T, Pio LC, Ramos HH, Ferreira LR (2010) Proteção de plantas: tecnologia de aplicação dos agroquímicos e equipamentos. Viçosa, UFV, 73p.

Mercante E, Souza EG, Johann JA, Gabriel Filho A, Uribe-Opazo MA (2010) Praprag - software para planejamento racional de máquinas agrícolas. Engenharia Agrícola 30(2):322-333. Available:

http://www.scielo.br/scielo.php?pid=S010069162010000200015\&script=sci_abstract\&tlng=pt. DOI: http://dx.doi.org/10.1590/S0100-69162010000200015

Mialhe LG (1974) Manual de mecanização agrícola. São Paulo, Agronômica Ceres, 301p.

Niari SM, Ranjbar I, Rashidi M (2012) Prediction of repair and maintenance costs of john deere 4955 tractors in Ardabil Province, Iran. World Applied Sciences Journal 19(10):1412-1416. Available:

https://pdfs.semanticscholar.org/9c0f/7d93e2f447def $2 \mathrm{c} 5 \mathrm{db}$ ada5f122b8831d0e4f.pdf. DOI:

http://dx.doi.org/10.5829/idosi.wasj.2012.19.10.2799

Oakland J (2007) Gerenciamento da qualidade total tqm. São Paulo, Ed. Nobel, 459p.

Oduma O, Igwe JE, Ntunde DI (2015) Performance evaluation of field efficiencies of some tractor drawn implements in Ebonyi State. International Journal of Engineering and Technology 5(4):199-204. Available: http://iet-

journals.org/archive/2015/april_vol_5_no_4/379621417162541.pdf.

PBA AVIATION (2012) Conheça o ipanema. PBA AVIATION. Available:

http://www.pbaaviation.com.br/index.php?option=com_co ntent $\&$ view $=$ article $\& i d=58 \&$ Itemid $=58 \&$ showall $=1$. Accessed: Fev 03, 2014.

Rashidi M, Ranjbar I (2010) Modeling of repair and maintenance costs of john deere 4955 tractors in Iran. American-Eurasian Journal of Agricultural \& Environmental Sciences 9(6):605-609. Available: https://www.idosi.org/aejaes/jaes9(6)/3.pdf. 
Rivera R, Sánchez N, Ríos G (2012) Determinación de la eficiencia de campo para el sistema de máquinas de alza y transporte en el ingenio pantaleón utilizando diagramas cíclicos, en la zafra azucarera 2010/2011. Nexo Revista Científica 25(2):54-58. Available: http://www.revistas.uni.edu.ni/index.php/nexo/article/view /81. DOI: http://dx.doi.org/10.5377/nexo.v25i2.676

Rohani A, Abbaspour-Fard MH, Abdolahpour S (2011) Prediction of tractor repair and maintenance costs using Artificial Neural Network. Expert Systems with Applications 38(7):8999-9007. Available:

https:/www.sciencedirect.com/science/article/pii/S09574174 11001382. DOI: https://doi.org/10.1016/j.eswa.2011.01.118

Santos NB dos, Fernandes HC, Gadanha Júnior CD (2015) Economic impact of sugarcane (Saccharum spp.) loss in mechanical harvesting. Científica 43(1):16-21. Available: http://cientifica.org.br/index.php/cientifica/article/viewFile /595/367. DOI: http://dx.doi.org/10.15361/1984-

5529.2015v43n1p16-21

Santos NB dos (2017) Method to determine unsuitable days for agricultural spraying. Nucleus 14(1):141-144. Available:

http://www.nucleus.feituverava.com.br/index.php/nucleus/ article/view/2161. DOI:

http://dx.doi.org/10.3738/1982.2278.2161

Santos NB dos, Teixeira MM, Fernandes HC, Gadanha Júnior, CD (2018) Analysis of times and efficiencies of the mechanized harvest of sugarcane (Saccharum spp.).

Nucleus 15(1):181-188. Available:

https://nucleus.feituverava.com.br/index.php/nucleus/articl e/view/2794/2599. DOI:

http://dx.doi.org/10.3738/1982.2278.2794
Sichonany OR de AO, Schlosser JF, Medina RD, Roggia IB, Lôbo JS, Santos FB dos (2011) Sistema computacional de gerenciamento para acompanhamento de desempenho de máquinas agrícolas instrumentadas com sensores. Ciência Rural 41(10):1773-1776. Available: http://www.scielo.br/scielo.php?pid=S0103$84782011001000016 \&$ script $=$ sci_abstract\&tlng=pt. DOI: http://dx.doi.org/10.1590/S0103-84782011001000016

Shamshiri R, Ismail WIW (2013) Exploring gps data for operational analysis of farm machinery. Research Journal of Applied Sciences, Engineering and Technology 5(12):3281-3286. Available:

http://maxwellsci.com/jp/abstract.php?jid=RJASET\&no=2 $90 \& \mathrm{abs}=04$.

UDOP - União dos Produtores de Bioenergia (2016) Preço cana campo (São Paulo). UDOP. Available: http://www.udop.com.br/graficos/cana_campo.php. Accessed: Nov 30, 2016.

Yousif LA, Dahab MH, El Ramlawi HR (2013) Cropmachinery management system for field operations and farm machinery selection. Journal of Agricultural Biotechnology and Sustainable Development 5(5):84-90. Available:

http://www.academicjournals.org/article/article137949572 4_Yousif\%20et\%20al.pdf. DOI: http://dx.doi.org/10.5897/JABSD2013.0205

Zaied MB, El Naim AM, Mahmoud TE (2014) Computer modeling for prediction of implement field performance variables. World Journal of Agricultural Research 2(2):3741. Available: http://pubs.sciepub.com/wjar/2/2/1/. DOI: http://dx.doi.org/10.12691/wjar-2-2-1

Zhou K, Jensen AL, Bochtis DD, Sørensen CG (2015) Performance of machinery in potato production in one growing season. Spanish Journal of Agricultural Research 13(4):1-12. Available:

http://revistas.inia.es/index.php/sjar/article/view/7448/263

8. DOI: http://dx.doi.org/10.5424/sjar/2015134-7448 